\title{
Novos saberes, sentidos e significados, por meio de práticas geradas por indivíduos em relação
}

\author{
New knowledge, senses and meanings by means of practices generated by interrelated individuals
}

Nuevos saberes, sentidos y significados, por medio de prácticas producidas por individuos en relación

Madel Therezinha Luz ${ }^{1}$

César Sabino ${ }^{2}$

Ao nos acercarmos do texto de Tullio Seppilli, um autor, a nosso ver, clássico da antropologia médica, a primeira atitude é de respeito. Sabemos que não encontraremos deslizes e que se trata de um autor com experiência teórica - e de campo - cujas bases se assentam nos clássicos da disciplina. Seppilli inova teoricamente, entretanto, ao trazer, para o campo de reflexão da antropologia social, o pensamento político de Gramsci, com duas de suas categorias centrais, isto é, hegemonia e coerção, necessárias - embora raramente utilizadas - para se entenderem processos de mudança na história da cultura humana.

Neste trabalho, o autor nos traz, além desta questão, digna de acolhimento e aprofundamento posterior, a questão central das ciências humanas em relação à vida, ou das relações entre elas e as ciências da vida, presente no pensamento social desde o fim do século XIX e não resolvida até o momento, a nosso ver. Em outras palavras, como explicar diferenciações individuais e culturais sem levar em consideração os condicionamentos humanos vitais (biológicos, seguindo aqui Seppilli) e sem considerar que eles se dão (sempre se deram, desde as origens da história) em contexto social, isto é, em redes de relações interindividuais, que definem o perfil específico dos seres que denominamos humanos? Esta questão é fundante das ciências sociais, especialmente quando postas diante das ciências da vida, sobretudo da biologia, presentemente, das biociências.

Entretanto, outra questão que está nos fundamentos das ciências humanas é justamente a inexplicável - ou, até hoje, insuficientemente explicada - e irredutível diversidade individual dos seres humanos entre si, em fase das determinações biológicas, como das sociais, isto é, classes, raças, etnias, gêneros e tantas categorias quantas têm sido designadas para enquadrar socialmente a espécie humana. Com efeito, a individualidade humana é irredutível, a nosso ver, tanto ao determinismo biológico quanto ao social.

A questão não se resume, portanto, à dicotomia biológica versus social, discutida por nosso autor no presente texto, mas a uma "tri-cotomia". Designando-a em termos adjetivos, são as três irredutíveis dimensões humanas: biológica, psicoemocional e social.

O setor discursivo das ciências humanas que se ocupa das questões individuais do sujeito humano está nas disciplinas "psi" (psicanálise e psicologia, com todas as suas correntes, controvérsias, acordos e desacordos). A densidade factual e teórica

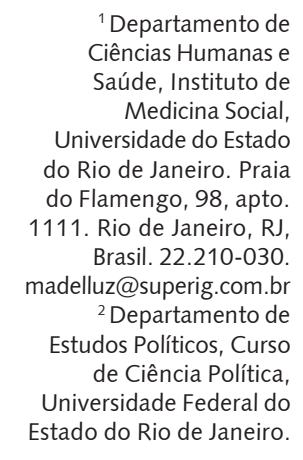

Ciências Humanas e Saúde, Instituto de Universidade do Estado do Rio de Janeiro. Praia 11. Rio de Janeiro, RJ, Brasil. 22.210-030. 2@superig.com.br udos Políticos, Curso Universidade Federal do Estado do Rio de Janeiro. 
que essas disciplinas alcançaram obriga-nos a considerar o fato humano - e, em decorrência, o fato cultural - não como bidimensional (biológico e social), mas como tridimensional. Em outras palavras, biopsicossocial (Luz, 2008; Mauss, 1974).

Embora o autor escreva sobre a importância de compreendermos os estados emocionais na produção das doenças orgânicas, e dos "aspectos psíquicos de tipo depressivo" relacionados à produção de doenças infecciosas, e, nesta vertente, destaque à contribuição da psiconeuroendocrinologia para a compreensão da intermediação psíquica entre estímulos relacionais e os processos físicos, seu texto não confere destaque maior à dimensão singular da subjetividade humana, tratando-a, mesmo, como categoria residual. Embora o texto contribua significativamente para o esclarecimento da importância da dimensão social na constituição do ser humano - e, por conseguinte, para o seu adoecimento e cura Seppilli não confere, a nosso ver, o devido destaque à terceira dimensão (psicológica), também fundamental para esta formação.

É verdade que a literatura antropológica, continuamente, tem demarcado sua singularidade entre ela e as chamadas ciências "psi"; porém, a importância das dimensões psicológicas não foi esquecida mesmo nos primórdios da formação disciplinar das ciências sociais. O problema está presente desde os debates do final do século XIX, atravessando o século XX, com as escolas funcionalista e estruturalista, chegando, hoje, aos desdobramentos dos "pós-estruturalismos", presentes tanto na sociologia de Pierre Bourdieu e seus seguidores, quanto na antropologia e na etnologia de Eduardo Viveiros de Castro e Philippe Descola, citando alguns poucos exemplos.

Em 1923, Mauss, ampliando o conceito de fato social de Durkheim, elabora a concepção de fato ou fenômeno social total (defendida no clássico Ensaio sobre a dádiva), ressaltando que os fatos sociais seriam não apenas pluricausados, pois consistiriam em elementos econômicos, religiosos, políticos, jurídicos etc., simultâneos, mas também apresentariam o fator psicológico como elemento fundamental para sua formação.

Neste aspecto, Mauss sugere ser importante, para o pesquisador, não esquecer (devido ao fato de seu método dividir, reduzir, parcelar e abstrair) que a realidade é, por fim, sistêmica e indivisível. Mais do que isso: é necessário destacar que o fato social total se encarna sempre em uma experiência individual, visto serem os humanos integrais, não divididos em faculdades ou peças necessitando, também, de atenção a sua subjetividade, posto ser a vida em sociedade apenas um dos fragmentos que os constitui como tais (Lévi-Strauss, 1974; Mauss, 1974).

Lévi-Strauss, seguindo a trilha desta abordagem, que caracterizará a chamada escola sociológica francesa, marca a importância do inconsciente estrutural como item característico de um saber - o antropológico - que além de ser uma espécie de astronomia das ciências sociais, também não deixaria de ser um tipo de psicologia, pois apesar de "os mitos se pensarem nos homens", o indivíduo, com sua singularidade existencial e criativa, seria fundamental para a existência das sociedades, já que sem "os esforços encarniçados [...] e o poder imaginativo da parte de alguns indivíduos", a descoberta de soluções fundamentais e a invenção de técnicas realizadas, em grande parte, pela observação e experimentação de alguns, as inúmeras e singulares soluções para os universais problemas humanos não teriam sido encontradas. Destarte, "as sociedades a que chamamos primitivas não têm menos homens como um Pasteur ou um Palissy do que as outras" (Lévi-Strauss, 1976, p.82).

Seríamos injustos se não destacássemos que Sepilli descreve as dimensões psicológicas como fundamentais na configuração do que chamamos ser humano. Aliás, o autor chega a esboçar a concepção desta dimensão como espécie de intersecção entre o nível biológico e o social (por ele denominado relacional), sendo os problemas de integração, neste último nível, uma das causas principais do adoecimento psíquico e, mesmo, orgânico. Todavia, esta hipótese não é plenamente desenvolvida no texto, embora esteja sugerida de forma brilhante. Gostaríamos de frisar que, apesar de citar o texto clássico de Lévi-Strauss sobre a eficácia simbólica para tratar a subjetividade como intermediação entre o que denomina como os dois níveis fundamentais, o autor italiano poderia ter enriquecido a questão da subjetividade e sua importância na dinâmica social se abordasse, por exemplo, o problema do inconsciente estrutural e o papel fundamental do subconsciente nesta abordagem. $O$ subconsciente seria a instância na qual cada um de nós, singularmente, acumularia experiências e intensidades únicas, compondo histórias pessoais, léxico individual, singular e di-ferente (Lévi-Strauss, 
1975). Talvez esta seja uma dimensão que mereça maior atenção dos pesquisadores das ciências sociais aplicadas à saúde. É possível que, nesta dimensão molecular, as experimentações micropolíticas venham produzir brechas no funcionamento opressivo dos sistemas sociais, liberando processos de singularização que sugerem novas solidariedades e, portanto, novas dinâmicas sociais (Luz, 2008, 2003; Deleuze, Guattari, 2010,1997). Em outras palavras: se a ausência de solidariedade pesa sobre a subjetividade e a psique do indivíduo no capitalismo atual, provocando, entre outros fatos, o adoecimento, a perda do sentido da vida e o suicídio, há também produção de novos saberes, sentidos e significados, por meio de práticas geradas por indivíduos em relação.

\section{Referências}

DELEUZE, G.; GUATTARI, F. O anti-Édipo. Rio de Janeiro: Ed. 34, 2010.

Mil platôs: capitalismo e esquizofrenia. Rio de Janeiro: Ed. 34, 1997. v.3.

LÉVI-STRAUSS, C. Raça e história. In: (Org.). Obras incompletas. São Paulo: Abril Cultural, 1976. p.51-94. (Coleção Os Pensadores)

A eficácia simbólica. In: Janeiro: Tempo Brasileiro, 1975. p.214-36.

Introdução à obra de Marcel Mauss. In: MAUSS, M. (Org.). Sociologia e antropologia. São Paulo: Edusp, 1974. v. 1. p.1-36.

LUZ, M.T. Notas sobre a política de produtividade em pesquisa no Brasil: conseqüências para a vida acadêmica, a ética no trabalho e a saúde dos trabalhadores. Polit. Soc. - Rev. Sociol. Pol., v.7, n.13, p.205-28, 2008.

Novos saberes e práticas em saúde coletiva: estudos sobre racionalidades médicas e atividades corporais. São Paulo: Hucitec, 2003.

MAUSS, M. Ensaio sobre a dádiva: forma e razão da troca nas sociedades arcaicas. In: (Org.). Sociologia e antropologia.São Paulo: Edusp, 1974. v.2, p.39-184. 